\title{
Metabolism of the Germinating Sclerotium of Claviceps purpurea
}

\author{
By K. CORBETT, A. G. DICKERSON AND P. G. MANTLE \\ Biochemistry Department, Imperial College, London $\mathrm{SW}_{7} 2 \mathrm{AZ}$
}

(Received 9 December I974; revised. 6 March I975)

\begin{abstract}
SUMMARY
The concentrations of free amino acids, particularly alanine, altered as stromata developed on germinating sclerotia. Lipid reserves in the sclerotium provided the principal carbon and energy source, and the nutrients required for stromatal growth appeared to be provided by the sclerotial tissues immediately beneath the point of attachment of the stroma. Alkaloid did not disappear from the sclerotia during germination. Very high levels of polyol, particularly mannitol, were attained in the stromata as germination progressed; the synthesis of polyol was usually accompanied by that of soluble sugars, notably glucose. In an attempt to ascertain the role of mannitol in germination, the relationship between polyol and soluble sugars was investigated in excised stromata after their submergence in buffered media containing a variety of soluble carbohydrates. Mannitol was synthesized under these conditions by way of phosphorylated intermediates, and chiefly in the capitulum, after rapid, and probably passive, absorption of the exogenously supplied sugar. The tissues equilibrated rapidly with the supplied carbohydrate, whose concentration was maintained by further uptake whilst mannitol was being synthesized. The concentrations of assimilated glucose and synthesized mannitol tended toward the same value during incubation and the results suggested that the synthesis was compartmentalized within the stromata. Very little exogenously supplied mannitol was assimilated.
\end{abstract}

\section{INTRODUCTION}

The initiation, development and function of the stromatal (sexual) stage of Claviceps purpurea, after what appears to be an obligatory cold treatment period of several weeks, are vital parts of the life cycle of this fungus and provide a model for a biochemical and physiological study of two contrasting tissues - the compact sclerotial tissue of the ergot, the large lipid content of which is mobilized to produce the soft ephemeral stroma, the latter having much greater metabolic activity. There is little recent information on stromatal initiation, development and function except by Cooke \& Mitchell (I966, I967, I969, I970) and Mitchell $\&$ Cooke $(1968 a, b)$. The present studies are an extension of investigations of the metabolism of $C$. purpurea during parasitic development on the host (Corbett, Dickerson \& Mantle, I974) and concern changes during the germination of sclerotia.

\section{METHODS}

Sclerotia. The origins of the ergot sclerotia are summarized in Table $\mathbf{I}$.

Germination conditions. Sclerotia were surface-sterilized for $5 \mathrm{~min}$ in $0.0 \mathrm{I} \%(\mathrm{w} / \mathrm{v}) \mathrm{HgCl}_{2}$ solution followed by five washes with sterile distilled water. The sclerotia were placed in trays on the surface of moist sterile sand and incubated at $3{ }^{\circ} \mathrm{C}$ for 6 weeks under a polythene sheet. The trays were inspected weekly and wetted when necessary to maintain damp sand. 
Table I. Origin of experimental ergot sclerotia

\begin{tabular}{|c|c|c|c|}
\hline Sample & Year & Host & Location \\
\hline $\mathbf{A}$ & 1968 & Rye & Bourne, Lincolnshire \\
\hline B & 1969 & Fourex rye & $\begin{array}{l}\text { Chelsea Physic Garden, London (Corbett } \\
\text { et al. 1974, strain 12-2) }\end{array}$ \\
\hline $\mathrm{C}^{*}$ & 1969 & Phalaris arundinacea & $\begin{array}{l}\text { Lathkilldale, Derbyshire (source similar to } \\
\text { that of Mitchell \& Cooke, } 1968 b \text { ) }\end{array}$ \\
\hline $\mathrm{D} \dagger$ & 1970 & Wheat & $\begin{array}{l}\text { National Institute of Agricultural Botany, } \\
\text { Cambridge }\end{array}$ \\
\hline E & I970 & Arrhenatherun elatius & Freshwater, Isle of Wight \\
\hline $\mathrm{F}$ & 1970 & Rye & Irish Institute of Standards, Dublin \\
\hline
\end{tabular}

* Lipid $36 \%$ (w/w). Fatty-acid composition typical of Claviceps purpurea (Mantle, Morris \& Hall, I969). Alkaloid $0.50 \%$; mainly ergotamine, some ergotoxine.

$\dagger$ Alkaloid $0.36 \%$; mainly ergotoxine and ergotamine.

After 6 weeks the trays were brought to laboratory temperature (about $18^{\circ} \mathrm{C}$ ), and kept moist and partly covered with polythene.

Design of 'course of development' experiment. One $100 \mathrm{~g}$ lot and four $6 \mathrm{~g}$ lots of ergot sclerotia (sample A) were prepared for the initiation of germination as above. The $6 \mathrm{~g}$ lots were removed after 2, 4, 6 and 8 weeks, homogenized in a Vortex mixer and immediately freeze-dried. Samples were taken from the $\mathrm{I} 00 \mathrm{~g}$ lot as the sclerotia germinated and presented stromata at different stages of development. The first sign of germination (at 9 weeks) was determined by the cracking of the cortical tissues of the sclerotium to reveal stromatal initials. The dry weight of stromatal tissue at this stage was negligible. The mid-germination stage comprised stromata about I cm long, with well-differentiated capitula but containing immature perithecia. The mature-stromatal stage comprised a predominance of stromata able to eject mature ascospores. At II weeks some sclerotia bearing mature stromata were separated from stromata and replaced on moist sand to develop a second flush of stromata. Samples were subsequently taken at mid-germination and mature-stromata stages (I5 weeks), and also at this time a sample of undisturbed sclerotia bearing senescent stromata was taken. Total germination in the $100 \mathrm{~g}$ lot was $42 \%$; samples taken at 2, 4, 6 and 8 weeks probably had approximately the same capacity for subsequent germination. Thus, whereas the composition of earlier samples was probably fairly uniform, the subsequent samples were selective and represented only those sclerotia which were able to germinate, i.e. less than half of the original population.

Collection of ascospores. Sclerotia bearing mature stromata were attached by petroleum jelly to the underside of a glass Petri dish lid so that the capitula lay inverted about $7 \mathrm{~mm}$ above the surface of a clean glass slide which had been placed on moist filter paper in the bottom of the dish. Discharged ascospores became deposited on the slide in an area about $5 \mathrm{~mm}$ in diameter. After several hours the deposition, clearly visible as an opaque area, could be removed by scraping with a sharp scalpel edge.

Extraction of ascospores. Spores ( $<\mathrm{I} \mathrm{mg}$ ) were washed twice with $\mathrm{I} \mathrm{ml}$ applications of water. A few drops of diethyl ether were added to the spores after the second washing and the mixture, in a small tube, was immersed in liquid nitrogen for $15 \mathrm{~min}$, then slowly brought to room temperature. Microscopic examination showed complete breakage of the spores. After the ether had evaporated the spores were extracted by the method of Corbett et al. (1974), using I $\mathrm{ml}$ of extractant on each occasion.

Incubation of tissue. The incubation of fungal tissues was standardized thus: $7.5 \%(\mathrm{w} / \mathrm{v})$ 
solutions of glucose, sucrose or mannitol were made up in 2 mM-sodium phosphate buffer at $\mathrm{pH} 7$; the solutions contained $7 \cdot 5 \mu \mathrm{Ci}$ of ${ }^{14} \mathrm{C} / \mathrm{ml}$. Sterile conditions were maintained as far as possible by the addition of $0.05 \mathrm{mg}$ aureomycin $/ \mathrm{ml}$ incubating medium and by placing the medium in a sterile tube provided with a cotton-wool plug. The tissues to be incubated were washed twice, each time with $\mathrm{I} \mathrm{ml}$ of the above buffer for every $300 \mathrm{mg}$ fresh weight of tissue. Washed tissues were incubated by shaking in a water bath at $25^{\circ} \mathrm{C}$; I ml of medium was used for every 150 to $500 \mathrm{mg}$ fresh weight of tissue and, where possible, the maximum weight indicated was used. Sampling was carried out by removing a known weight of tissue and a proportional amount of the medium, to keep the ratio of the initial tissue weight to medium volume as near constant as possible. Samples were extracted by the procedure previously described after washing as above.

Assay of radioactivity. Products from incubation media and from tissue extracts were separated by paper chromatography and the dried papers exposed to Kodirex No-screen $\mathrm{X}$-ray film. The autoradiograph was used to locate the radioactive areas, which were removed, cut into small pieces (IO $\times 10 \mathrm{~mm}$ ) and immersed in $10 \mathrm{ml}$ of liquid scintillant [6 g 5-(4-biphenylyl)-2-(4-t-butylphenyl)-I-oxa-3,4-diazole $+50 \mathrm{~g}$ naphthalene/l toluene]. Samples in aqueous solution were placed in the above scintillant and converted into a single-phase system by adding 2-methoxyethanol (Methylcellosolve). The radioactivity in the samples was determined in a Packard counter (model 3003). Corrections for variable efficiencies were made.

From the known specific radioactivity of the carbohydrate initially supplied, the concentrations of ${ }^{14} \mathrm{C}$-labelled sugars found in the media and tissues after incubation were determined, assuming that no reactions involving ${ }^{12} \mathrm{C}-{ }^{14} \mathrm{C}$ exchange occurred.

Chemical analyses. Analytical techniques for alkaloid, lipid, free amino acids and soluble carbohydrates were as described by Corbett et al. (1974).

Chromatography and quantitative estimation of carbohydrates. The methods were essentially those of Corbett et al. (1974). Quantitative determination of soluble carbohydrates was mainly by g.l.c., as previously described, either directly, following silylation of dried samples of incubation media and extracts, or after the carbohydrates had been isolated by paper chromatography before silylation.

Oligofructosides and sugar phosphates were isolated on paper chromatograms as the areas having a chromatographic mobility relative to sucrose $\left(R_{\text {sucrose }}\right)$ between $0.35-0.8 \mathrm{I}$ and $0.03-0.30$, respectively (Dickerson, 1972).

\section{RESULTS}

\section{Course of stromatal initiation and development}

Changes in the concentration of carbohydrates, lipid, amino acids and alkaloid during sclerotial germination are summarized in Table 2.

As a result of the initial part of the cold treatment of the sclerotia there was a small increase in the concentration of several amino acids (Table 3 ) but subsequently there was a general fall in total free amino acids until germination commenced. Nine weeks after starting the cold treatment there appeared the first morphological signs of stromatal initiation and this was associated with a general increase in amino acid concentration, most notably of alanine, but also of threonine, serine and glutamic acid. This flux continued during the subsequent proliferation of stromata. Alanine became the major component and valine replaced glutamic acid as the second most abundant amino acid. By I I weeks the stromata appeared to be fully developed, and separate analysis of sclerotial and stromatal components showed 
Table 2. Composition of carbohydrate, lipid, amino acids and alkaloid in sample $A$ ergot sclerotia during the course of stromatal initiation and development

\begin{tabular}{|c|c|c|c|c|c|c|c|}
\hline & & Carbohyd & te $(\mu \mathrm{g} / \mathrm{mg}$ & ze dry wt) & & & Free amino \\
\hline We & & $\begin{array}{l}\text { Soluble* } \\
\text { sugars }\end{array}$ & Polyol $\dagger$ & Glucose & $\begin{array}{c}\text { Lipid } \\
(\%, w / w)\end{array}$ & $\begin{array}{l}\text { Alkaloid } \\
(\%, w / w)\end{array}$ & $\begin{array}{r}(\mu \mathrm{mol} / \mathrm{IOO} \mathrm{mg} \\
\text { freeze-dried } \mathrm{wt})\end{array}$ \\
\hline o) & & 55 & 0 & 10 & $3 I \S$ & 0.25 & $7 \cdot 6$ \\
\hline 2$\}$ & & - & 0 & 0.5 & $24 \cdot I$ & 0.25 & $8 \cdot 2$ \\
\hline 4 & Cola treatment & 一 & 0 & 0.25 & $27 \cdot 0$ & 0.19 & $4 \cdot 6$ \\
\hline 6) & & 35 & 0 & $5 \cdot 0$ & $26 \cdot 6$ & 0.20 & $3 \cdot 5$ \\
\hline 8 & & 一 & - & - & $26 \cdot 0$ & $0.2 \mathrm{I}$ & $3 \cdot 2$ \\
\hline 9 & Early germination & 18 & 5 & 0.3 & $25 \cdot I$ & $0 \cdot 10$ & $4 \cdot 8$ \\
\hline 10 & Mid germination & 20 & 15 & 0.3 & $30 \cdot 5$ & $0 \cdot I_{I}$ & $8 \cdot 2$ \\
\hline I I & $\begin{array}{l}\text { Sclerotia + mature } \\
\text { stromata }\end{array}$ & 60 & 43 & I I 5 & $20 \cdot 5$ & 0.25 & - \\
\hline I I & Sclerotial fraction & 33 & 27 & $\mathrm{I} \cdot 3$ & $28 \cdot 6$ & 0.20 & $4 \cdot 6$ \\
\hline I I & Stromatal fraction & 73 & 58 & $I \cdot 6$ & $I \cdot 6$ & - & $10 \cdot 2$ \\
\hline 12 & $\begin{array}{l}\text { Early germination } \\
\text { (2nd flush) }\end{array}$ & 一 & $\mathrm{I} \cdot 5$ & $2 \cdot 2$ & $27 \cdot 2$ & 0.30 & $4 \cdot 3$ \\
\hline 15 & $\begin{array}{l}\text { Mature stromata }+ \\
\text { sclerotia (2nd flush) }\end{array}$ & 一 & $6 \cdot 5$ & $14 \cdot 5$ & - & - & $6 \cdot 6$ \\
\hline I5 & $\begin{array}{l}\text { Exhausted Ist-flush } \\
\text { sclerotia fraction }\end{array}$ & - & $3 \cdot 0$ & $I \cdot O$ & $18 \cdot 4$ & 0.22 & $5 \cdot I$ \\
\hline 15 & $\begin{array}{l}\text { Exhausted Ist-flush } \\
\text { stromatal fraction }\end{array}$ & - & $5 \cdot 0$ & $1 \cdot 0$ & 一 & 一 & $6 \cdot 7$ \\
\hline 15 & Ungerminated & 一 & 一 & - & $2 I \cdot 6$ & 0.15 & 3.9 \\
\hline
\end{tabular}

* Similar concentrations of total sugars and glucose were found in non-germinated ergots of strain I2-2 (Corbett et al. 1974).

$\dagger$ More than $90 \%$ as mannitol. Rest mainly arabinitol.

¥ Alkaloid composition: mainly ergotoxine, some ergotamine, little ergometrine.

$\S$ Fell to $16 \%$ after oven drying sclerotia at $100^{\circ} \mathrm{C}$ for $24 \mathrm{~h}$ (Mitchell \& Cooke, 1968a). This apparent reduction in lipid content was assumed to be due to loss of volatile material. The water content of sclerotia under laboratory conditions is $1 \mathrm{I} \cdot 5 \%(\mathrm{w} / \mathrm{w})$. The increase of fresh weight due to imbibition of water during 2 weeks cold treatment is $75 \%$.

the stromata to be richer in free amino acids. On a dry weight basis, the alanine concentration was approximately sevenfold greater than that of the sclerotia from which the stromata had emerged. In the stromata, valine and glutamic acid remained abundant and threonine and serine attained comparable concentrations. By comparison with all earlier samples, cysteine had attained a large value in the sclerotial fractions and an even greater abundance in the stromata. Excision of the first flush of stromata at I I weeks resulted in the sclerotia producing a second flush of initials I week later but the amino acid composition altered little until the stromata had attained their full size. The abundance of alanine in the sclerotial and stromatal tissues became as notable a feature as in the first-flush tissues. However, the total concentration of free amino acids was rather less in the second flush of stromata. The unidentified amino acid A was an important component of all samples. Arginine was present, but incomplete separation from ammonia precluded quantitative evaluation. Determination of lysine presented difficulties in the autoanalytical procedure employed, on account of the sharpness of the peak and the frequency with which the peak exceeded the scale, but it was always an important component. The amino acid composition of samples of nongerminated sclerotia taken during the 9 to 15 week period was consistently similar to that of the 8 week sample, thereby confirming that the high concentration of alanine during stromatal development reflected the intense metabolic activity during stromatal growth.

The quantity of triglyceride oil (lipid, Table 2) extracted from sclerotia was about $25 \%$ 


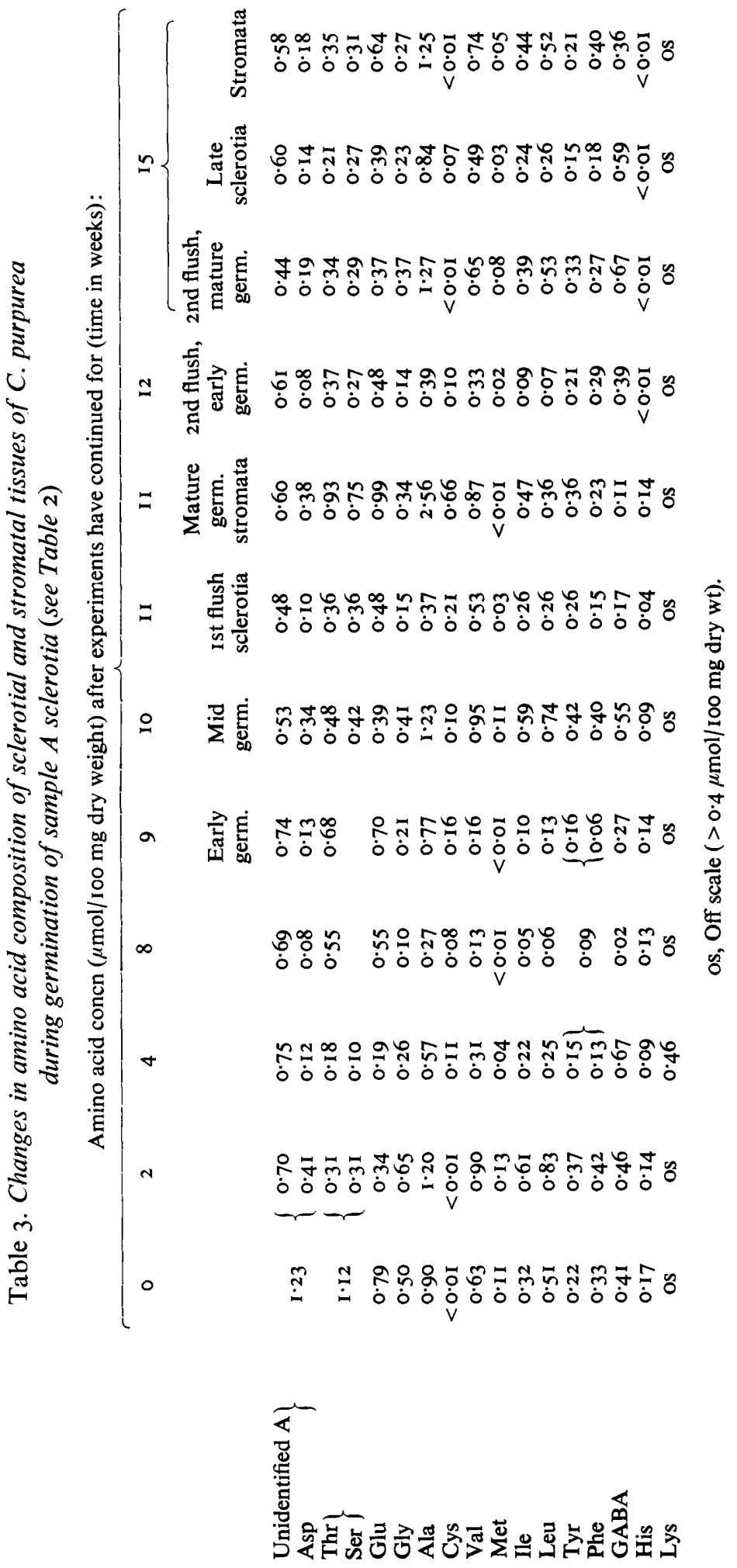


Table 4. Fatty-acid composition of triglyceride oils of stromatal tissues of C. purpurea

\begin{tabular}{|c|c|c|c|c|c|c|c|c|}
\hline & \multicolumn{8}{|c|}{ Fatty-acid composition $(\%, w / w)$} \\
\hline & $14: 0$ & $16: 0$ & $16: 1$ & $18: 0$ & I8: I & I8:2 & $18: 3$ & I 8: I-OH \\
\hline $\begin{array}{l}\text { Fully developed rye ergot } \\
\text { stromata (Table 2, I I-week } \\
\text { sample) }\end{array}$ & 0.4 & $77 \cdot 0$ & 0.0 & $17 \cdot 9$ & $3 \cdot 2$ & $I \cdot 5$ & 0.0 & 0.0 \\
\hline \multicolumn{9}{|l|}{$\begin{array}{l}\text { Sample E ergots } \\
\text { Stromata }\end{array}$} \\
\hline $\begin{array}{r}\text { Stromata } \\
\text { Capitula }\end{array}$ & $\mathrm{I} \cdot 4$ & $23 \cdot 4$ & $I \cdot I$ & $4 \cdot 9$ & 12.9 & $44 \cdot 5$ & II $\cdot 8$ & 0.0 \\
\hline Stipes & $\begin{array}{ll}2 \\
I\end{array} 6$ & $38 \cdot 2$ & $2 \cdot 6$ & $6 \cdot 6$ & $5 \cdot 8$ & $45 \cdot 2$ & 0.0 & $0 \cdot 0$ \\
\hline \multicolumn{9}{|l|}{ Sample B ergots } \\
\hline Normal & $\mathrm{I} \cdot 4$ & I $8 \cdot I$ & $2 \cdot 9$ & 3.9 & $9 \cdot 3$ & $48 \cdot 4$ & $16 \cdot 0$ & 0.0 \\
\hline $\begin{array}{l}\text { Abnormal, no differentiation of } \\
\text { capitula }\end{array}$ & 0.7 & $18 \cdot 2$ & $2 \cdot 4$ & $3 \cdot 0$ & $6 \cdot 3$ & $69 \cdot I$ & 0.0 & $0 \cdot 0$ \\
\hline Sample F ergots & & & & & & & & \\
\hline $\begin{array}{l}\text { Whole stromata } \\
\text { Older stromata divided into }\end{array}$ & 0.0 & $46 \cdot 4$ & $14 \cdot 2$ & $10 \cdot 5$ & 15.5 & $6 \cdot 8$ & $6 \cdot 6$ & 0.0 \\
\hline Capitula & 0.0 & $78 \cdot 0$ & $6 \cdot 0$ & $16 \cdot 0$ & 0.0 & 0.0 & 0.0 & 0.0 \\
\hline Stipes & 0.0 & $74 \cdot 6$ & $9 \cdot 8$ & $15 \cdot 6$ & 0.0 & 0.0 & 0.0 & 0.0 \\
\hline
\end{tabular}

$(w / w)$ during germination. Much of the variation $( \pm 5 \%)$ was to be expected, in view of the selective sampling and the differences between the individual sclerotia in a sample. Although there was some evidence that sclerotia which had yielded many stromata had a slightly reduced lipid content, there was clearly no consistent depletion of lipid reserves disproportionate to the depletion of other utilizable nutrient reserve components of the sclerotium. The stromata contained only a trace of triglyceride oil, but this was exceptionally rich in saturated fatty acids (Table 4 ).

Similarly, the total alkaloid composition varied at about $0.25 \%(w / w)$ but the relative proportions of the component alkaloids remained approximately constant throughout. Apart from the rather lower alkaloid content of the 9- and I0-week samples, which may indicate that the sclerotia containing less alkaloid germinate earlier than others, the process of stromatal initiation and development was not accompanied by any general depletion of alkaloid within the sclerotia.

\section{Utilization of sclerotial lipid in the development of stromata}

Germinating ergots from Arrhenatherum elatius (sample E) were used for this experiment on account of their smooth surfaces and regular shapes. Only those sclerotia which had given rise to single or paired stromata from one point on the surface were used and, after excision of the terminal $\mathrm{I} \mathrm{mm}$ segments to convert the ergots into regular cylinders, each sclerotium was separated by transverse section into: (i) the segment immediately giving rise to the stromata (after excision of the stromata at the base of the stipe) and (ii) the segments free from stromata. Determination of the total lipid content (Table 5) showed that there was rather less lipid in the tissues immediately adjacent to the stromata. This would be consistent with a hypothesis that stromatal development is principally a very local event utilizing lipid reserves in the medullary tissues immediately below the attachment of the stromatal stipe.

The sclerotial oil from all samples producing experimental stromata was analysed and the fatty-acid composition approximated closely to the reported composition of ergot oils (Morris \& Hall, 1966). Thus any triglyceride oils present in stromatal tissues were assumed to have 
Table 5. Comparative distribution of lipid in stromata and sclerotia of C. purpurea

$\begin{array}{lc}\text { Sample F ergot stromata } & \begin{array}{c}\text { Lipid } \\ \text { (\% of dry wt) }\end{array} \\ \text { Sample E ergots } & 5 \cdot 5 \\ \quad \text { Sclerotial segment yielding stromata } & 16 \cdot \mathbf{I} \\ \quad \text { Sclerotial segments not yielding stromata } & 17 \cdot 5 \\ \quad \begin{array}{l}\text { Stromata excised from sclerotial segments } \\ \quad \text { above, plus other similar stromata }\end{array} & \\ \quad \text { Capitula } & 4 \cdot 5 \\ \quad \text { Stipes } & 2 \cdot 2 \\ \text { Sample B ergots } & \\ \quad \text { Normal stromata } & 8 \cdot 3 \\ \text { Abnormal stromata } & 3 \cdot 0\end{array}$

been derived from sclerotial oil either by direct translocation or by resynthesis from metabolites derived from sclerotial breakdown lipid.

Separation of Arrhenatherum elatius ergot stromata into capitular and stipe tissues followed by lipid extraction showed (Table 5) that the capitula accounted for nearly $40 \%$ of the stromatal dry weight and contained about twice as much lipid as the stipe tissues. The fatty-acid composition of the oils from these tissues (Table 4) showed that linolenic acid was restricted to the capitula, and that ricinoleic acid, the principal component of sclerotial oil, was absent from both capitula and stipes.

Similar differences between capitular and stipe oils were also observed when comparing the typical and atypical stromata which arose from sclerotia of $C$. purpurea strain I2-2 (sample B). The abnormal stromata appeared as a disorganized proliferation of soft fleshy tissue (rather similar to the stipe tissue of normal stromata) in which no capitulum differentiated. As expected, this stipe-like tissue contained rather less total lipid than normal stromata and its fatty acid composition was deficient in linolenic acid, an important component of normal stromata. Again, the absence of ricinoleic acid indicates that stromatal oils are not simply translocated sclerotial oils.

The fatty-acid composition of the trace $(\mathrm{I} \cdot 6 \% \mathrm{w} / \mathrm{w})$ of oil from fully developed stromata, most of which may have ejected their ascospores, was exceptionally rich (95\%) in saturated fatty acids, chiefly palmitic. A similar composition was found in the older mature stromata of the Irish rye ergots (sample F), and separation into capitulum and stipe tissues did not reveal any significant feature of the capitular oil. This suggests that a triglyceride oil containing linolenic acid may be associated with the ascogenous phase of the capitular development but becomes dissipated during or after ascospore discharge.

\section{Alkaloid content of sclerotia}

Since it was known that the ergots of sample $F$ were particularly rich in alkaloid, a comparison was made between germinated and ungerminated sclerotia with respect to the amount of alkaloid present, as a percentage of the air-dry ( 3 days at laboratory temperature) weight. Germinated sclerotia of variable size and from which a crop of fully developed stromata had been removed contained $0.65 \%(w / w)$ alkaloid, whereas a group of ungerminated, though similarly treated, sclerotia contained only $0.39 \%$ alkaloid. It was concluded that the apparent increase of alkaloid as a result of germination was at least partly an artefact due to the depletion of dry matter during proliferation of the excised stromata. The experiment was therefore modified to include size-matching of sclerotia assigned to the two groups. This resulted in alkaloid contents of 0.56 and $0.49 \%$ for germinated and 
Table 6. Carbohydrate composition of sclerotia, stromata and ascospores of various ergot samples

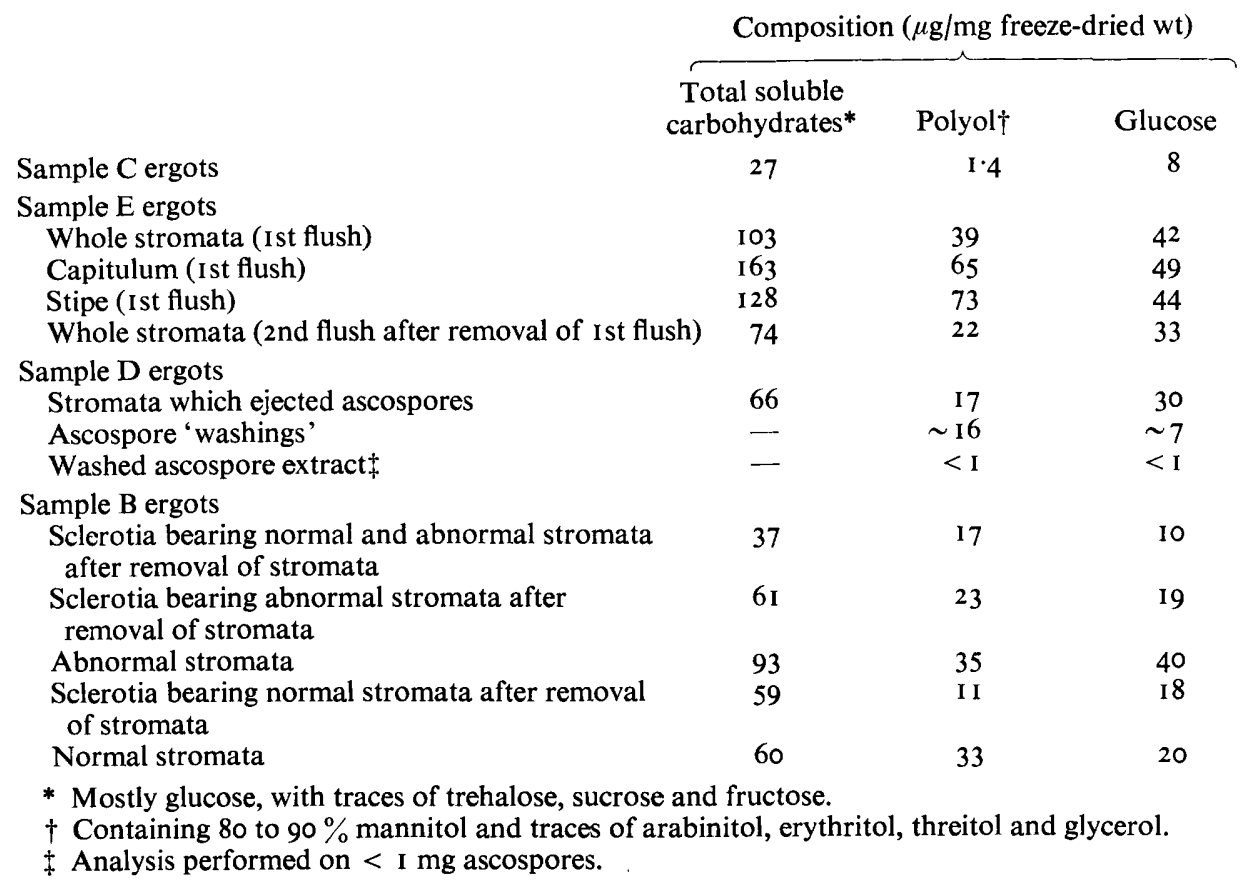

ungerminated sclerotia, respectively, and the total lipid contents were 20.7 and $23.8 \%$. The moderate depletion of lipid was in accord with earlier experiments. The slight increase in alkaloid content is regarded as indicating that alkaloid is not catabolized to any great extent during the germination process, and also is probably not synthesized.

\section{Assimilation and synthesis of soluble carbohydrates by stromata}

Tables 2 and 6 show that germination of sclerotia was accompanied by a sharp increase in soluble carbohydrates, particularly mannitol and, to a lesser and variable extent, glucose. We attempted to investigate the biosynthesis of polyol and to determine whether there was any correlation between the incidence of polyol and other sugars, notably glucose.

Fig. I (a) shows the levels of glucose and mannitol in isolated stromata as determined by isotopic measurements on labelled material. During incubation of stromata in ${ }^{14} \mathrm{C}$-labelled glucose, a rapid uptake occurred which was almost complete within $30 \mathrm{~min}$. The level of labelled glucose was maintained by further uptake whilst some of it was slowly converted, primarily, to ${ }^{14} \mathrm{C}$-labelled mannitol, in the stromata. Sugar phosphates were also formed and their synthesis paralleled the uptake of glucose. The concentrations of the two labelled carbohydrates approached each other; by $4 \mathrm{~h}$ the concentration of mannitol was $70 \%$ that of glucose. Fig. I $(b)$ shows the total mannitol and glucose concentrations in the stromata during the incubation period as derived from g.l.c. measurements (i.e. these values include any unlabelled material in addition to the ${ }^{14} \mathrm{C}$-labelled material). The increase in glucose as determined by the isotopic values alone (Fig. $\mathrm{I} a$ ) is nearly identical with that obtained by the g.l.c. measurements (Fig. I $b$ ); it is therefore clear that the increase of glucose in the stromata was solely due to that taken up from the medium. However, the g.l.c. values 

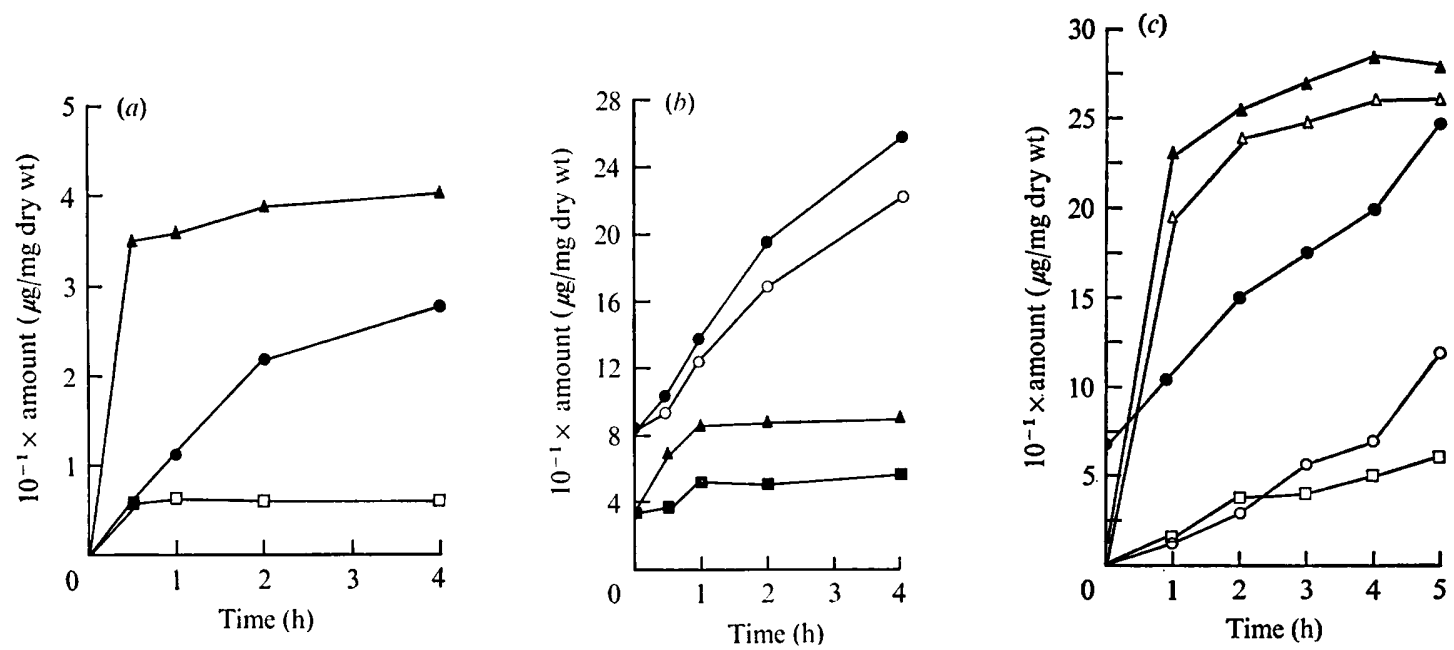

Fig. I. Synthesis of mannitol. For incubation procedure, see text. (a) Synthesis of ${ }^{14} \mathrm{C}$-labelled mannitol in stromata of $C$. purpurea submerged in a medium containing ${ }^{14} \mathrm{C}$-labelled glucose. $\boldsymbol{\Delta}$, Glucose assimilated;, , mannitol synthesized; $\square$, sugar phosphate synthesized (hexose equivalent). (b) Synthesis of ${ }^{14} \mathrm{C}$-labelled and unlabelled mannitol, combined, by stromata of C. purpurea submerged in a medium containing ${ }^{14} \mathrm{C}$-labelled glucose. $\square$, Intrinsic glucose (i.e. total glucose concentration as determined by g.l.c. less glucose concentration as determined from its isotopic label only); $\boldsymbol{\Delta}$, intrinsic glucose + assimilated glucose; $O$, intrinsic mannitol; $\boldsymbol{O}$, intrinsic mannitol+synthesized mannitol. (c) Synthesis of ${ }^{14} \mathrm{C}$-labelled and unlabelled mannitol, combined, by capitula of Claviceps purpurea submerged in a medium containing ${ }^{14} \mathrm{C}$-labelled glucose. $\boldsymbol{\Delta}$, intrinsic glucose + assimilated glucose; $\triangle$, assimilated glucose; $\bullet$, intrinsic mannitol+ synthesized mannitol; $\bigcirc$, synthesized mannitol; $\square$, synthesized sugar phosphate (hexose equivalent).

indicate a substantially greater increase in the mannitol than can be accounted for by the increase in labelled material alone, and show that mannitol was being synthesized from other sources besides exogenously supplied glucose.

The response to exogenously supplied glucose of the capitulum and the stipe (which was divided into three segments) showed that the abilities of the four parts to take up glucose from the medium were not substantially different, although the base (which contained most glucose initially) appeared to be the most efficient (Table 7). However, the capitulum region was the site of maximum synthesis of polyol. A concentration gradient of both polyol and hexose occurred up the stromata; that of hexose was most marked since there was virtually no glucose in the capitulum under normal conditions. This correlates well with the greater ability of the capitulum to convert glucose to mannitol.

On the basis of data in Table 7, the experiment illustrated in Fig. I $(b)$ with whole stromata was repeated using capitula only (Fig. I $c$ ), as were all subsequent experiments. The results from this experiment confirm those shown in Fig. I $(a)$ and $(b)$, the main difference being, as expected, the low initial level of endogenous glucose. An increase in mannitol, in excess of that which could be accounted for by supplied glucose, was again observed. Capitula were therefore incubated in the same medium as before but without glucose; no significant changes were observed in any soluble carbohydrates except mannitol, which increased from I5. I to $37 \cdot 8 \mu \mathrm{g} / \mathrm{mg}$ dry weight in $5 \mathrm{~h}$.

After pre-soaking the tissues for $\mathrm{I} h$ in $0.1 \mathrm{~mm}$-ouabain, or $5 \mathrm{~mm}$-iodoacetate $+\mathrm{I} \mathrm{mM}$ $\mathrm{NaCN}$, or all three transport inhibitors together (Glynn, 1956; Caldwell, I960; Caldwell et al. 1960), the tissues were incubated in a medium containing glucose in addition to the 


\section{Table 7. Synthesis of mannitol by excised stromata of C. purpurea}

For incubation procedure, see text. The stipes were divided in basipetal succession into three segments, I, 2 and 3, of equal length.

\begin{tabular}{|c|c|c|c|c|c|c|}
\hline \multirow[b]{2}{*}{$\begin{array}{l}\text { Incubation } \\
\text { period (h) }\end{array}$} & \multicolumn{3}{|c|}{ Glucose $(\mu \mathrm{g} / \mathrm{mg}$ dry wt) } & \multicolumn{3}{|c|}{ Mannitol ( $\mu \mathrm{g} / \mathrm{mg}$ dry wt) } \\
\hline & 0 & 2 & 5 & 0 & 2 & 5 \\
\hline \multicolumn{7}{|c|}{ Glucose or mannitol content of tissues* } \\
\hline Capitulum & 0.7 & $8 I \cdot I$ & $85 \cdot 6$ & $88 \cdot 0$ & $99 \cdot 5$ & I I $8 \cdot 6$ \\
\hline Segment I & $4 \cdot 6$ & $74 \cdot 3$ & $103 \cdot 0$ & $99 \cdot 2$ & I $10 \cdot 7$ & I $15 \cdot 5$ \\
\hline Segment 2 & $20 \cdot 0$ & I $14 \cdot 1$ & $134 \cdot 8$ & 138.6 & $144 \cdot 4$ & $147 \cdot 5$ \\
\hline Segment 3 & $84 \cdot 6$ & $187 \cdot 7$ & $192 \cdot 8$ & 138.8 & $14 I \cdot 6$ & $144 \cdot 5$ \\
\hline \multicolumn{7}{|c|}{ Glucose assimilated, or mannitol synthesized, by tissues $\dagger$} \\
\hline Capitulum & - & $80 \cdot 0$ & $84 \cdot 2$ & - & I I $\cdot 3$ & $32 \cdot I$ \\
\hline Segment I & - & $70 \cdot 2$ & $98 \cdot 6$ & - & $8 \cdot 9$ & $15 \cdot 8$ \\
\hline Segment 2 & - & $9 I \cdot 4$ & II $2 \cdot 7$ & - & $3 \cdot 9$ & $6 \cdot 9$ \\
\hline Segment 3 & - & $102 \cdot I$ & I 10.9 & 一 & $3 \cdot 6$ & $5 \cdot 4$ \\
\hline
\end{tabular}

Sugar phosphate synthesized $\dagger$

\begin{tabular}{|c|c|c|c|}
\hline \multirow{2}{*}{$\begin{array}{l}\text { Incubation } \\
\text { period (h) }\end{array}$} & \multicolumn{3}{|c|}{ ( $\mu \mathrm{g} / \mathrm{mg}$ dry wt - hexose equivalent) } \\
\hline & 0 & 2 & 5 \\
\hline Capitulum & - & $6 \cdot I$ & $9 \cdot 2$ \\
\hline Segment I & - & $6 \cdot 4$ & $7 \cdot 6$ \\
\hline Segment 2 & - & $4 \cdot 6$ & $5 \cdot 8$ \\
\hline Segment 3 & - & $3 \cdot 8$ & $4 \cdot 4$ \\
\hline
\end{tabular}

various inhibitors, to test whether the high rate of glucose uptake was active or passive. No influence on the levels and rate of uptake of glucose or on the subsequent synthesis of polyol was observed.

Table 8 shows the effect of the age of the capitulum on its ability to take up glucose from the media and to synthesize mannitol. The capitulum was most active in taking up glucose during its first 2 weeks of development on the sclerotium; its synthetic ability reached a maximum during the second and third weeks, with combined levels of glucose + mannitol exceeding $20 \%(\mathrm{w} / \mathrm{w})$. However, even at 6 weeks the capitula still remained active in both respects. Incubations at 2-day intervals from the 8th to 22 nd day of development established that the fall in ability to absorb glucose commenced at Io days and was complete by the 2oth day; synthetic ability, on the other hand, was not observed to any marked degree until the roth day.

In parallel experiments, the glucose in the incubation medium was sometimes replaced by mannitol or sucrose. In a number of experiments, the absorption of mannitol was in the range $2 \%$ to approximately $20 \%$ of that of glucose. The conversion of mannitol to other metabolites in the tissues was very low; in a typical experiment the level of synthesized glucose was $5 \%$ of the mannitol taken up at $3 \mathrm{~h}$ (Table 9). No synthesis of other sugars or polyols could be detected. As when glucose was the substrate, the period of greatest absorption preceded that of maximum synthetic activity during stromatal development (Table 9).

Capitula were also incubated with sucrose as substrate (Table Io). As noted before, the assimilation of substrate from the medium was greatest after Io days' development, but in the case of sucrose an initial rapid uptake was followed by a marked fall after $3 \mathrm{~h}$. Mannitol was not synthesized in significant quantities until I 6 days, by which time the levels of free 
Table 8. Effect of age of capitula on their ability to assimilate glucose and synthesize mannitol

For incubation procedure, see text. There was no incorporation into arabinitol (total concn 2 to $10 \mu \mathrm{g} / \mathrm{mg}$ dry wt) but $\mathrm{I}$ to $2 \mu \mathrm{g} / \mathrm{mg}$ dry $\mathrm{wt} / \mathrm{h}$ were incorporated into fructose (total concn 12 to $18 \mu \mathrm{g} / \mathrm{mg}$ dry wt).

\begin{tabular}{|c|c|c|c|c|c|c|}
\hline \multirow{2}{*}{$\begin{array}{l}\text { Age of } \\
\text { capitula } \\
\text { (weeks) }\end{array}$} & \multirow{2}{*}{$\begin{array}{l}\text { Incubation } \\
\text { period } \\
\text { (h) }\end{array}$} & \multicolumn{2}{|c|}{ Glucose $(\mu \mathrm{g} / \mathrm{mg}$ dry $w \mathrm{t})$} & \multicolumn{2}{|c|}{ Mannitol ( $\mu \mathrm{g} / \mathrm{mg}$ dry wt) } & \multirow{2}{*}{$\begin{array}{c}\text { Glucose } \\
\text { assimilated } \\
\text { from medium } \\
(\%)\end{array}$} \\
\hline & & Total* & Assimilated $\dagger$ & Total* & Synthesized $\dagger$ & \\
\hline I & 4 & 257 & 260 & 19 & 5 & 8 \\
\hline 2 & 4 & II3 & I 18 & 103 & 32 & $5 \cdot 5$ \\
\hline 3 & I & 44 & 45 & 71 & 19 & - \\
\hline 3 & 4 & 49 & 48 & 95 & 47 & 8 \\
\hline 4 & I & 33 & 32 & 66 & 16 & - \\
\hline 4 & 4 & 50 & 52 & 88 & 40 & 10 \\
\hline 5 & 0 & $<\mathrm{I}$ & - & 24 & $\longrightarrow$ & 一 \\
\hline 5 & 0.5 & 45 & 42 & 16 & 4 & - \\
\hline 5 & 3 & 54 & 48 & 50 & 28 & 8 \\
\hline 6 & 0 & $<\mathrm{I}$ & - & 6 & - & 一 \\
\hline 6 & 0.5 & 50 & 47 & 3 & 3 & - \\
\hline 6 & 3 & 58 & 57 & $2 I$ & 23 & 8 \\
\hline
\end{tabular}

Table 9. Effect of age of capitula on their ability to assimilate mannitol and synthesize glucose

For incubation procedure, see text.

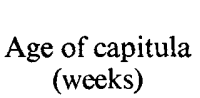

I

2

3

3

4
Incubation period

(h)

3
3
I
3
I
3

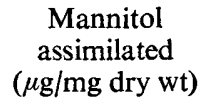

$8 \cdot 7$

$4 \cdot 3$

$3 \cdot 7$

$3 \cdot 7$

$3 \cdot 1$

$3 \cdot 1$
Glucose

synthesized $(\mu \mathrm{g} / \mathrm{mg}$ dry wt)

Table I0. Effect of age of capitula on their ability to assimilate sucrose and synthesize other metabolites

For incubation procedure, see text.

\begin{tabular}{|c|c|c|c|c|c|c|}
\hline \multirow[b]{2}{*}{$\begin{array}{l}\text { Age of } \\
\text { capitula } \\
\text { (days) }\end{array}$} & \multirow[b]{2}{*}{$\begin{array}{l}\text { Incubation } \\
\text { period } \\
(\mathrm{h})\end{array}$} & \multirow[b]{2}{*}{$\begin{array}{c}\text { Sucrose } \\
\text { assimilated } \\
(\mu \mathrm{g} / \mathrm{mg} \text { dry wt })\end{array}$} & \multicolumn{4}{|c|}{ Product synthesized $(\mu \mathrm{g} / \mathrm{mg}$ dry wt) } \\
\hline & & & Glucose & Fructose & Mannitol & $\begin{array}{l}\text { Oligo- } \\
\text { saccharides } \\
\text { and sugar } \\
\text { phosphates* }\end{array}$ \\
\hline 10 & 0.5 & $86 \cdot 2$ & $5 \cdot 6$ & $3 \cdot 1$ & $\mathrm{I} \cdot 2$ & $8 \cdot I$ \\
\hline 10 & $3 \cdot 0$ & $26 \cdot 7$ & $12 \cdot 4$ & $8 \cdot 7$ & $I \cdot 2$ & $43 \cdot 4$ \\
\hline I 2 & 0.5 & $35 \cdot 3$ & $5 \cdot 6$ & $3 \cdot 7$ & $I \cdot 2$ & 15.5 \\
\hline 12 & $3 \cdot 0$ & $9 \cdot 9$ & $19 \cdot 2$ & $16 \cdot I$ & $3 \cdot I$ & $27 \cdot 3$ \\
\hline 16 & 0.5 & $37 \cdot 8$ & I I $\cdot 8$ & $9 \cdot 3$ & $6 \cdot 2$ & $22 \cdot 3$ \\
\hline 16 & $3 \cdot 0$ & $3 \cdot 7$ & $22 \cdot 9$ & $22 \cdot 3$ & $34 \cdot 5$ & $22 \cdot 3$ \\
\hline 22 & 0.5 & $19 \cdot 8$ & II $\cdot 2$ & $12 \cdot 4$ & $9 \cdot 3$ & 15.5 \\
\hline 22 & $3 \cdot 0$ & $3 \cdot 7$ & 18.6 & $22 \cdot 9$ & $53 \cdot 9$ & $27 \cdot 3$ \\
\hline
\end{tabular}

* Hexose equivalent; the oligosaccharides accounted for 70 to $80 \%$ of the ${ }^{14} \mathrm{C}$ content of this fraction. 


\section{Table I I. Assimilation of glucose and synthesis of mannitol by mycelia of C. purpurea grown in axenic culture}

Mycelia of $C$. purpurea, strain $117 / 2 / \mathrm{SF}$, from shake culture (Dickerson et al. 1970) was harvested at 5 days and, after a brief washing with $10 \mathrm{~mm}$-sodium acetate buffer $\mathrm{pH} 5.2$ (IO $\mathrm{ml} / \mathrm{g}$ wet wt), was incubated under the same conditions as that described for the stromata.

\begin{tabular}{|c|c|c|c|c|}
\hline \multirow{2}{*}{$\begin{array}{l}\text { Incubation } \\
\text { period } \\
\text { (h) }\end{array}$} & \multicolumn{2}{|c|}{ Glucose $(\mu \mathrm{g} / \mathrm{mg}$ dry wt) } & \multicolumn{2}{|c|}{ Mannitol ( $\mu \mathrm{g} / \mathrm{mg}$ dry wt) } \\
\hline & Total & Assimilated & Total & Synthesized \\
\hline o & $10 \cdot 3$ & 0 & $12 \cdot 6$ & 0 \\
\hline $\mathbf{I}$ & $59 \cdot 2$ & $46 \cdot 0$ & $13 \cdot 2$ & $I \cdot 5$ \\
\hline 5 & $92 \cdot 6$ & $75 \cdot 6$ & $20 \cdot 8$ & $7 \cdot 5$ \\
\hline
\end{tabular}

glucose and fructose were also quite high. There was also a substantial synthesis of oligosaccharides containing glucose and fructose.

Table I I gives the results of an experiment in which stromatal tissue was replaced in the glucose incubate by an equivalent weight of filamentous mycelium of $C$. purpurea (strain I $7 / 2 / \mathrm{SF}$, Biochemistry Department, Imperial College) grown for 5 days in shaken liquid culture (Dickerson, Mantle \& Szczyrbak, 1970). The levels of uptake of glucose were similar to those obtained with stromata and the subsequent synthesis of mannitol corresponded in amount with that obtained using stromatal stipes rather than capitula.

\section{DISCUSSION}

Large changes in the concentrations of soluble metabolites in germinating sclerotia imply a high metabolic activity of stromatal tissues. Amongst the free amino acids, alanine showed the greatest increase associated with stromatal growth and reflected the abundance of amino acid synthesis and turnover expected in a sexually reproducing structure. The unidentified amino acid A, first reported as a feature of alkaloid-containing sclerotia by Corbett et al. (1974), persisted, together with the alkaloids in the sclerotium during germination, thus suggesting that they had no special function in the germination process. However, the unidentified amino acid A was, unlike alkaloid (Mantle, unpublished results), translocated to or synthesized in the stromata. This contrasts with the normal correlation between the presence of alkaloid and unidentified amino acid A in the sclerotium (Corbett et al. 1974).

Respiration studies (Garay, I958; Mitchell \& Cooke, I968 $b$; Dickerson, unpublished results) leave no doubt that lipid is the principal carbon reserve. The present studies show only a slight fall in the percentage $(w / w)$ of lipid during germination of large sclerotia. This may be explained by local utilization of sclerotial reserves directly beneath the stipe. In small grass ergots depletion of the sclerotial reserves in this way would involve a much greater proportion of the sclerotial volume and could well account for onset of the spongelike character and water-absorbing properties during germination of the Phalaris arundinacea ergots studied by Mitchell \& Cooke (1968 $b$ ). The absence of ricinoleate from stromatal triglyceride indicated that sclerotial oil was not translocated to the stromata, but there appeared to be distinctive (with respect to the presence of linoleate) triglycerides associated with ascus development in the capitulum.

Cooke \& Mitchell (1970), in discussing the role of chilling in breaking sclerotial dormancy, suggested that it removes a constraint on the conversion of sugar to mannitol. The suggestion was based on a marked accumulation of sugar during dormancy, a marked decrease in lipid before a detectable rise in respiration rate (Cooke \& Mitchell, I968 $b$ ) and a rise in mannitol concentration during germination concomitant with a decrease in sugar 
concentration. The present studies have been unable to confirm any of these premises; changes occurring during the chilling period did not show any consistent trends and were probably due to experimental differences arising from variations in the sclerotia comprising individual samples. Although there is no evidence to support the putative pathway for the conversion of lipid to mannitol proposed by Cooke \& Mitchell (1970), it is clear that the stromata of C. purpurea have a remarkable capacity for polyol, particularly mannitol, synthesis. It has been proposed that mannitol has a role in spore ejection (Cooke \& Mitchell, 1970) and results here show clearly that the capitulum is an important site of polyol synthesis. However, abnormal stromata that produced no ascospores were not deficient in polyol synthesis. The concentration of mannitol would not appear to be critical since both first- and secondflush normal stromata, which differed markedly in polyol content, were shown to eject ascospores.

Hexose, principally glucose, increased in concentration coincidentally with mannitol from the low level normally found in sclerotia $(<0.1 \%, w / w)$ to levels in excess of $1 \cdot 0 \%(w / w)$ in stromata. The abundant synthesis of mannitol in excised stromata during incubation in buffered medium was in excess of that which could have been formed from supplied glucose, often markedly so. The excised stromata contained triglyceride oil which could give rise to both hexose and polyol; it is not clear whether the synthesis of mannitol is normally preceded by that of the glucose. Nevertheless, a pathway from hexose to polyol, involving phosphorylated intermediates (details to be published) clearly exists for exogenously supplied glucose. This operated to the greatest extent in the capitulum of isolated stromata but it was also present in mycelia growth in axenic culture.

Data obtained by the use of inhibitors suggest that the uptake of glucose from the medium is passive. If the submerged capitulum absorbs the incubating medium over its entire surface, then the interhyphal space in the capitulum can be calculated to be as high as $40 \%$ of the total volume (Fig. I $c$, taking the steady-state concentration for glucose after absorption as $240 \mu \mathrm{g} / \mathrm{mg}$ dry weight, and the average capitulum to be a regular sphere of measured radius $0.8 \mathrm{~mm}$ and dry weight $0.5 \mathrm{mg}$ ). The steady-state concentration for glucose, and sugar phosphates derived therefrom, in the tissues after absorption was normally approached fairly rapidly (well within 30 min under the experimental conditions described) and was maintained over a period of at least 4 to $5 \mathrm{~h}$, during which time mannitol and other products were slowly synthesized. The concentrations of glucose and mannitol, as measured by their isotopic content only, tend towards the same value during incubation of the stromata; however, the total concentrations of these two carbohydrates did not approach each other. This shows that a pathway for the synthesis of mannitol from exogenously supplied sugar, particularly glucose, exists. This synthesis can take place at the same time as, but is largely separated from, the accumulation of mannitol by an alternative route. The latter is most likely to be the major route for stromata in the natural aerial condition where lipid supplied by the ergot is presumably the substrate. The situation with respect to sucrose and mannitol absorption is, however, more complex. With sucrose in the incubating medium, the initial rate of uptake is not maintained, and with mannitol a variable and normally low rate of absorption occurs. Utilization of the mannitol that is absorbed is negligible, but sucrose, when absorbed, gives rise to glucose, fructose and oligosaccharides which have been noted before (Dickerson, 1972); unlike the results obtained from the latter work on tissue derived from shake culture, it appears that the capitulum can utilize glucose or fructose with equal facility since the measured levels of the two hexoses are not sufficiently different to indicate that glucose is preferentially used for polyol synthesis. 


\section{REFERENCES}

Caldwell, P. C. (1960). The phosphorus metabolism of squid axons and its relationship to the active transport of sodium. Journal of Physiology 152, 545-560.

Caldwell, P. C., Hodgkin, A. L., Keynes, R. D. \& Shaw, T. I. (1960). The effect of injecting energy-rich phosphate compounds on the active transport of ions in the giant axons of Loligo. Journal of Physiology 152, 56I-590.

Cooke, R. C. \& Mitchell, D. T. (I966). Sclerotium size and germination in Claviceps purpurea. Transactions of the British Mycological Society 49, 95-100.

Cooke, R. C. \& Mitchell, D. T. (1967). Germination pattern and capacity for repeated stroma formation in Claviceps purpurea. Transactions of the British Mycological Society 50, 275-283.

Cooke, R. C. \& MitchelL, D. T. (1969). Sugars and polyols in sclerotia of Claviceps purpurea, C. nigricans and Sclerotinia curreyana during germination. Transactions of the British Mycological Society 52, $365-372$.

CoOKe, R. C. \& Mrtchell, D. T. (1970). Carbohydrate physiology of sclerotia of Claviceps purpurea during dormancy and germination. Transactions of the British Mycological Society 54, 93-99.

Corbett, K., Dickerson, A. G. \& Mantle, P. G. (I974). Metabolic studies on Claviceps purpurea during parasitic development on rye. Journal of General Microbiology 84, 39-58.

Dickerson, A. G. (1972). A $\beta$-D-fructofuranosidase from Claviceps purpurea. Biochemical Journal 129, $263-272$.

Dickerson, A. G., Mantle, P. G. \& Szczyrbak, C. A. (1970). Autolysis of extracellular glucans produced in vitro by a strain of Claviceps fusiformis. Journal of General Microbiology 60, 403-4I 5.

GARAY, A. S. (1958). Der Zusammenhang zwischen Fruchtkörperbildung und Atmung im Falle des Mutterkorns unter besonderer Berücksichtigung der Bedeutung der Fumärsaure. Physiologia plantarum rx, 48-55.

GlynN, I. M. (1956). Sodium and potassium movements in human red cells. Journal of Physiology 134, 278-3IO.

Mantle, P. G., Morris, L. J. \& Hall, S. W. (1969). Fatty acid composition of sphaecelial and sclerotial growth forms of Claviceps purpurea in relation to the production of ergoline alkaloids in culture. Transactions of the British Mycological Society 53, 44I-447.

Mitchell, D. T. \& Cooke, R. C. (1968a). Some effects of temperature on germination and longevity of sclerotia in Claviceps purpurea. Transactions of the British Mycological Society 51, 72 1-729.

Mrtchell, D. T. \& CoOKe, R. C. (I968b). Water uptake, respiration pattern and lipid utilisation in sclerotia of Claviceps purpurea during germination. Transactions of the British Mycological Society 5I, 73 I-736.

Morris, L. T. \& HALl, S. W. (1966). The structure of the glycerides of ergot oils. Lipids I, I88-196. 